\title{
Atypical atrial myxoma pending to the left atrial appendage: a diagnostic challenge
}

\author{
Ana Faustino, Rui Providência, Joana Trigo, Maria do Carmo Cachulo
}

Department of Cardiology, Coimbra's Hospital Centre and University, Coimbra, Portugal

\section{Correspondence to} Dr Rui Providência, rui_providencia@yahoo.com
To cite: Faustino $\mathrm{A}_{\text {, }}$ Providência R, Trigo J, et al. BMJ Case Reports Published online: [please include Day Month Year] doi:10.1136/ bcr-2012-007850

\section{DESCRIPTION}

A 53-year-old woman with a known history of hypertension and hypercholesterolaemia, under oral contraception, was admitted to the neurology department due to a lacunar stroke. She presented with a right motor deficit and dysarthria, and recovered in $48 \mathrm{~h}$. The cranial CT scan did not identify acute lesions. The ECG showed sinus rhythm. A transthoracic echocardiography was performed and no significant changes were found. On further evaluation, a transoesophageal echocardiography revealed an oval and pedunculated mass, with welldefined limits, measuring $1.3 \times 1.1 \mathrm{~cm}$, with a $0.2 \mathrm{~cm}$ peduncle adherent to the left atrium wall, between the left atrial appendage (LAA) and the upper left pulmonary vein (figure 1). This was highly mobile and very distensible, protruding to the LAA during atrial systole. The hypotheses of an intracardiac thrombus and tumour were placed. Oral anticoagulation was started and the patient underwent cardiac MRI (figure 2). This allowed tissue characterisation of the mass: intermediate signal intensity on T1-weighted and higher signal intensity on T2-weighted sequences (with and without fat suppression), with an intense gadolinium enhancement, excluding thrombus and suggesting myxoma. Owing to its embolic potential, the patient underwent surgical excision of the mass, due to its embolic potential, and the histological evaluation confirmed the diagnosis of atrial myxoma.

Primary cardiac tumours are rare $(0.05 \%) .{ }^{1}$ Atrial myxoma is the most common cardiac tumour $(50 \%)$, most frequently located in the left atrium (75\%), usually attached to the left atrial septum around the fossa ovalis. ${ }^{1-3}$ In $5 \%$ of cases myxoma may be located in the LAA. ${ }^{1}$

\section{Learning points}

- This case draws attention to an unusual location for atrial myxoma, which led to confusion with thrombus, challenging the differential diagnosis and the therapeutic approach.

- It also highlights the value of transoesophageal echocardiography in studying stroke aetiology at younger age, even when cardiovascular risk factors are present and the transthoracic echocardiography is normal.

- MRI was crucial in differential diagnosis by allowing tissue characterisation of the mass.
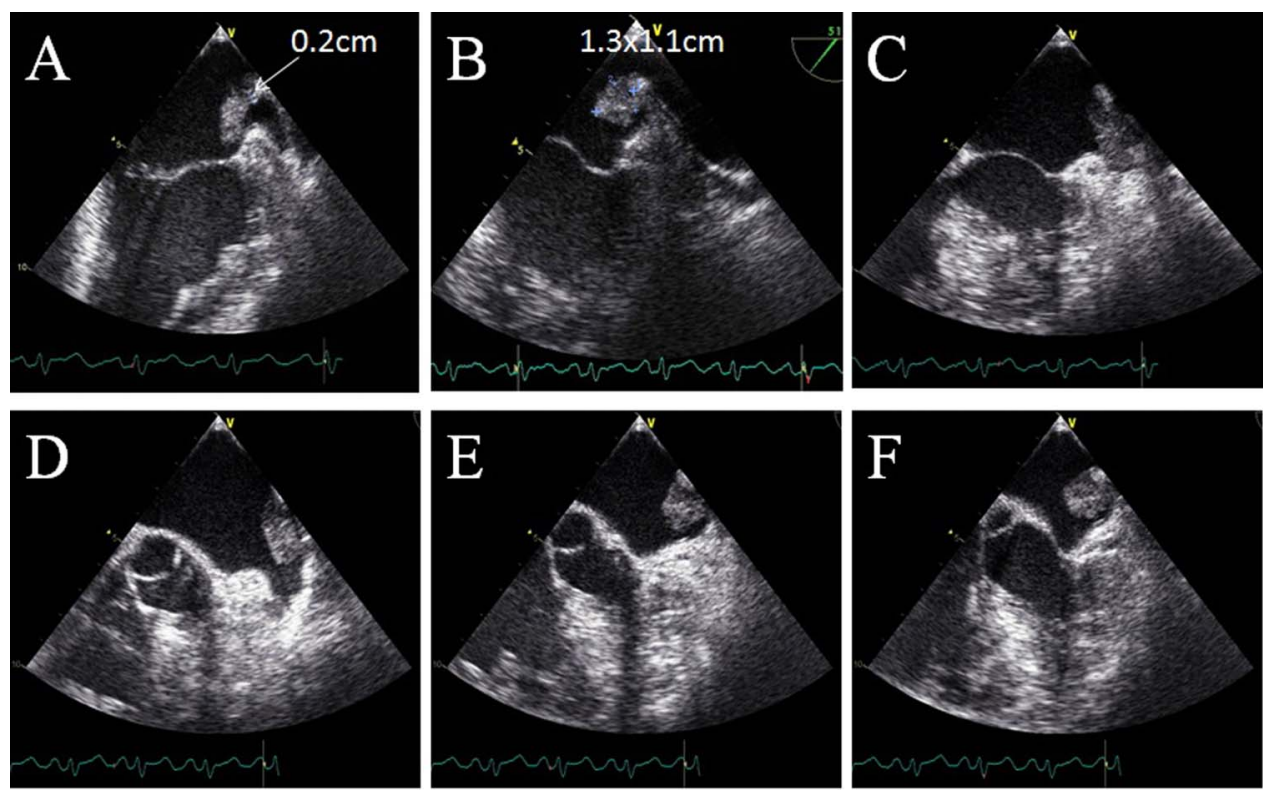

Figure 1 Transoesophageal echocardiography images showing the pedunculated mass protruding to the left atrial appendage (LAA) during atrial systole. (A) Two-chamber longitudinal plane at $88^{\circ}$ showing a pedicle with $0.2 \mathrm{~cm}$ wide. (B) Two-chamber longitudinal plane at $31^{\circ}$ with the dimensions of the mass; following the movement of the mass from its location inside the LAA (C: two-chamber longitudinal plane at $55^{\circ}$ ), and then going out with the LAA contraction (D: transverse plane at $45^{\circ}$ ), appearing in the lumen of the left atria ( $E$ and $F$ : transverse plane at $45^{\circ}$ ). 

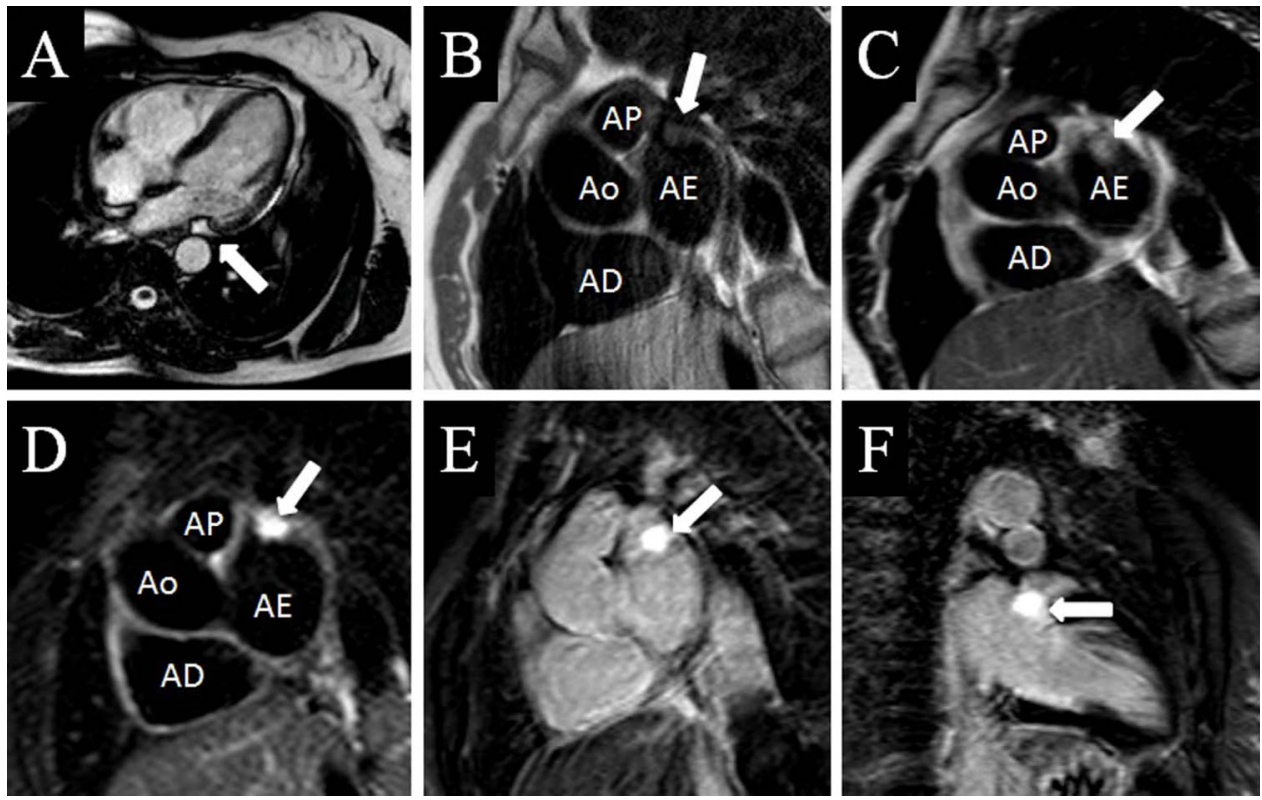

Figure $2 \mathrm{MRI}$ images showing the pedunculated mass (white arrows) located in the transition of the left atrium anterior wall to the left atrial appendage superior wall. (A) Four-chamber horizontal long-axis Cine sequence in transverse plane showing the mass protrusion into the LAA. (B) T1-weighted sequences in short axis with an intermediate signal intensity mass. (C) T2-weighted sequences in short axis identifying a hyperintense mass. (D) T2-weighted sequences with fat suppression in short axis showing a hyperintense mass. (E) Short axis after contrast with gadolinium revealing intense enhancement of the mass. $(F)$ Long axis after gadolinium contrast showing intense enhancement of the mass. $A D$, right atrium; $A E$, left atrium; Ao, aorta; $A P$, pulmonary artery.

Competing interests None.

Patient consent Obtained.

Provenance and peer review Not commissioned; externally peer reviewed.

\section{REFERENCES}

1 Shapiro LM, Cardiac tumours: diagnosis and management. Heart 2001;85:218-22. 2 Reynen K. Cardiac myxomas. N Engl J Med 1995;333:1610-17.

3 ÓDonnell DH, Abbara S, Chaithiraphan V, et al. Cardiac tumors: optimal cardiac MR sequences and spectrum of imaging appearances. AJR 2009;193:377-87.

Copyright 2013 BMJ Publishing Group. All rights reserved. For permission to reuse any of this content visit http://group.bmi.com/group/rights-licensing/permissions.

BMJ Case Report Fellows may re-use this article for personal use and teaching without any further permission.

Become a Fellow of BMJ Case Reports today and you can:

- Submit as many cases as you like

- Enjoy fast sympathetic peer review and rapid publication of accepted articles

- Access all the published articles

- Re-use any of the published material for personal use and teaching without further permission

For information on Institutional Fellowships contact consortiasales@bmjgroup.com

Visit casereports.bmj.com for more articles like this and to become a Fellow 